\title{
Competitiveness of Higher Education in Ukraine and Certain European Countries: Empirical Studies on Funding and Academic Attractiveness
}

\author{
HANNA KOTINA ${ }^{1}$, MARYNA STEPURA ${ }^{2}$, VIKTOR FEDOSOV ${ }^{3}$, DENYS HRYSOHLAZOV ${ }^{4}$, \\ MARINA BILINETS \\ Department of Finance ${ }^{1,2,3,4,5}$, Kyiv National Economic _University named after Vadym Hetman ${ }^{1,2,3,4,5}$, \\ UKRAINE
}

\begin{abstract}
The article deals with the competitiveness and funding of higher education in certain Eastern and Central European countries. The development of higher education is characterized by certain shortcomings that require the reform of higher education systems in such countries like Ukraine in the direction of ensuring the innovative development of education and forms of its funding. The trend of recent years shows an increased interest of students in international mobility. Unfortunately, this process can positively and negatively affect the attractiveness and competitiveness of higher education in the home country. An idea of the article is to verify does the decline in demand for higher education in home countries could be driven by the level of competitive higher education system or the costs of education, including the role of government quote on higher education. Secondly, determine the cause-effect relationships between the factors affecting the demand for higher education in the country and abroad. The results of the research confirm the strong dependence of the competitiveness of higher education system on the existing form of its financing (the direction of using funds in favor of development costs and the ratio of funding sources in the studied country) and academic attractiveness.
\end{abstract}

Key-Words: Competitiveness of Higher Education, Attractiveness of Higher Education, Quality of Higher Education System, Forms of Funding, Government Expenditure on Higher Education, Academic Mobility

Received: April 2, 2020. Revised: September 1, 2020, Accepted: September 7, 2020. Published: September 11, 2020.

\section{Introduction}

The development of higher education is characterized by certain shortcomings that require the reform of higher education systems in such countries like Ukraine in the direction of ensuring the innovative development of education and sustainable economic development of the state.

The quality of education still remains low at all levels in low- and middle-income countries. Students in developing countries have an average level of achievement lower than in industrialized countries, and their performance shows a much larger average difference. Delays in reforming education systems to keep pace with economic structures are most evident in the transition economies of Eastern and Central Europe. The backlog of reforms may hinder growth; on the contrary, timely reform can pay off in the face of economic growth and poverty reduction, as evidenced by East Asian countries, which usually invest enough money in human capital development [1].

The key to successful educational reforms is the unwavering commitment that policy should aim to improve students' educational achievement. In a world of structural and technological changes, it is important to emphasize the role of educational content in developing people's knowledge and skills. Higher education programs should provide sufficient general qualifications for their participants that will allow them to adapt to future changes in demand on labor market and emerging economic systems. However, high school graduates need to be especially aware of the need for a lifelong learning process to regularly update their skills. The structural and technological changes in the economy obviously require adaptation skills to the lifelong learning process [2]. Regardless of the quality of educational services, e-learning demand will drive the spread of digital education, similar to the rapidly growing privatization of education. The number of university students worldwide is estimated to increase from 214.1 million in 2015 to 594.1 million in 2040 [19]. And developing regions are experiencing high growth rates. As noted, governments face with problems in building expensive establishments amid fast-growing demand.

Reducing the demand for traditional education requires the use of new technologies in the educational process and the transformation of forms of student learning [24]. More and more universities, along with 
traditional education, are using e-learning opportunities, which, on the one hand, help to increase access to higher education for the population and, on the other, help reduce the costs of providing educational services, especially in the context of lower funding for higher education institutions through budgetary resources.

The purpose of the article is to explore and evaluate the relationships between the competitiveness, quality, attractiveness, innovation and funding for higher education in European countries in the context of a worldwide trends in traditional adult education and the development of ICT components in educational process.

The contribution is organized as following:

1. The second part is devoted to a literature review about quality, models of funding, attractiveness and innovativeness of higher education.

2. The third part describes the methodology of the research and sources of data.

3. The results of the calculations and their discussions are presented in the fourth part.

\section{Literature Review}

Education is considered as one of the key drivers of economic growth. Traditionally, it is defined as a set of skills, competences and other performance enhancement characteristics. In general, education, as an essential component of human capital, enhances the efficiency of the individual worker and helps the economies move towards economic growth [3]. Human capital, as an important component of the economic system, has made the impact of education on productivity growth.

It identifies three channels through which education affects labor productivity in the country. First of all, education contributes to the collective capacity of the workforce to fulfill existing tasks; secondly, secondary and higher education act as a kind of transfer of knowledge and information; thirdly, it contributes to the country's capacity to generate new knowledge, products and technologies [4].

Studies of human capital have shown that the formation of human capital (education and health care) plays a decisive role in the economic development of the country [23]. Better level of education does not only contribute to raising individual income, but is also a prerequisite for long-term economic growth [5]. Researches conducted by scientists show that education plays a crucial role in the prosperity of the individual and society. Education is a leading driver of economic growth, employment and wages. Ignoring education threatens the prosperity of future generations, which is reflected in the effects of poverty, social exclusion and the disadvantages of the welfare system [6]. UNESCO's research has shown that every $\$ 1$ spent on education generates $\$ 10$ to $\$ 15$ in economic growth. If $75 \%$ of students aged 15 and older in the 46 poorest countries reached the lowest OECD mark in mathematics, while the economic growth of these countries could improve average by $2.1 \%$ from the baseline, as a result 104 million people could leave the poverty line [7].

Determining the role of education in economic growth should be based not only on the analysis of quantitative indicators - the percentage of the population with an appropriate level of education, but, importantly with quality of education. For example, a study notes that not only years of schooling but also the quality of education has a significant impact on economic growth [8]. It should be noted that the WEF evaluates the level of secondary and higher education through training of specialists and quality of education on the basis of assessments of business leaders and levels of training of staff. Empirical studies have shown that there is a significant correlation between people's knowledge and long-term economic growth [25]. As result, the orientation of countries on the development of human capital, as a driver of economic growth, has led to unrestricted attention to the educational achievements that most clearly characterize the quality of education. Without improving the quality of education, it is difficult for countries to improve economic performance in the long period.

A review of the literature shows that quality education is closely linked with individual and society prosperity, which is reflected in earnings, employment and economic growth. A 50-point increase in educational achievement PISA at the country level increases economic growth prospects by $1 \%$. Among the working population, income increases by an average of $7.4 \%$ for each additional year of study, or if knowledge is measured on a PIAAC scale, by $17.4 \%$ for each step on a five-step competence scale [2]. Higher education quality should be ensured by an appropriate funding model.

In general, there are three models of financing higher education in the economic literature [10]:

1. Bureaucratic, which implies complete control by the state with direct intervention in all spheres of university life - determination of staff, number of students, areas of preparation and research. Universities must comply with all government regulations.

2. Collegiate, under which the universities subsidized by the state, but at the same time can attract private funds (in the form of contract training, project research activities, financing of certain programs and scholarships), and distribute them independently. 
Although budget funding is a large part of university financial resources, the oversight of the activities of the university is carried out by a specially authorized body, not by the government. At the same time, this model is characterized by a certain financial autonomy of the universities and colleges.

3. A market in which financially autonomous higher educational institutions (HEIs), which operate traditionally at the expense of students and businesses, should actively cooperate with internal (students, researchers and teachers) and external (partners, customers, suppliers, creditors) stakeholders, as well as the government, which ensures the achievement of public interest. The role of the state in this case narrows down to setting priority of education, demand facilitation, while HEAs become more transparent, accountable and investment-friendly in order to be competitive in national and international markets.

The analysis shows that most countries use a combination of different approaches to higher education funding. Its traditional source (public funds) is usually complemented by incentive tools. In practice, there are the following mechanisms for financing higher education: budget negotiations with the spending unit; pre-financing funding; formulabased financing; performance contracts; financing of special research projects received on the basis of the competition [11]. The current model of higher education funding is result based funding, since it focusses on improving progress and completing student learning, as it is not based on input but output. In many countries, performance contracts have been successfully implemented and include the following: student learning outcomes, graduate employment, graduate earnings, number of higher education degrees, number of foreign students, international mobility, and others [12]. Funding for universities at the expense of budgetary resources requires monitoring the effectiveness of the university's activities in general and costs in particular. University rankings are a recognized indicator of its effectiveness; however, empirical studies have not found a permanent positive correlation between funding size and university rankings. At the same time, the analysis showed that universities funded through negotiations, unlike to formal models (formal funding and performance contracts), show better performance in the ranking. However, no correlation was found between the size of state grants and the rating of universities, so in such circumstances the mechanism of state funding seems to be a more important factor over the size of funding $[13,21]$.

The evaluation of the attractiveness of higher education in the economic literature is based on two indicators: 1. The ratio between the number of applicants and students for each higher education program; 2. Average school grade point. However, competition for training places depends on the number of training places. The country's focus on the effective development of higher education systems has facilitated the transition from norm assessment to goal evaluation of programs. In this regard, the attractiveness index is defined as the grade point average of students admitted to the relevant higher education program. With regard to national higher education systems, their attractiveness to international students is assessed by such indicators as: the number of national HEIs in the academic rankings of world universities; R\&D expenditures; the presence of a common border, a common language and colonial connections in the past. Significant negative factor in the attractiveness is the distance, and the positive is the cost of education and living in the country of study [14, 15]. Central institutions need to understand that attractiveness is a dynamic phenomenon, interacting with the local context and the economic cycle. Solving a problem with accessibility, quality assurance and excellence, they must take into account that institutions need to adapt to changing contexts, and they can contribute to sustainability by setting long-term goals rather than by assessing short-term dynamics [16]. This has particular importance for the policy of financing higher education institutions.

Recently the active introduction of digital technologies in public services [26] in European countries requires strengthening the quality of the innovative component of higher education. A review of the literature on higher education innovation has identified major drivers of innovation in this sector: the pressure of globalization (increasing international mobility of workforce and students, the emergence of new institutional formats, increased harmonization of national policies, especially in areas such as quality assurance, qualifications and links with the labor market, as well as strong competition for foreign students and the global achievement); - changing demand and supply for higher education (using technology as a means to improve student productivity and learning through new online teaching and learning environments that develop alongside traditional forms and, in some cases, begin to replace them); - changes in the financing of higher education (rising spending on education with funding cuts, especially the expense of budgetary funds) [17].

Funding for distance education is mainly through the investment of own resources, which a barrier for those who do not have these resources. That is why it does not contribute to reducing social inequality [18]. Because of this, there must be various funding options and assistance with securing the 
appropriate funding source. However, e-learning will play an increasingly important complementary role in mainstream education, driven by the need to reduce costs and meet demand [19]. Disabled social segments will increasingly receive education through distance learning using mobile phones; while elite universities will gradually incorporate digital content into blended learning models. Online education will also be increasingly used in vocational education and training for adults.

\section{Methodology}

Based on mentioned above, without any doubt high-quality and competitive higher education system is a driver of human capital development, evolving of the labor market and has an impact on the sustainable economic development of the country. That is why the system of funding of higher education should be aimed at enhancing its competitiveness and attractiveness, given into account the current downward trend of interest of the population in higher education at the home country. The results of our research over the last 15 years indicate that the number of tertiary students in Ukraine has decreased by almost 2 times, nevertheless the gross enrolment ratio shows a steady smooth trend. In addition, the decline in higher education demand is also caused by the migration of students (Fig. 1).

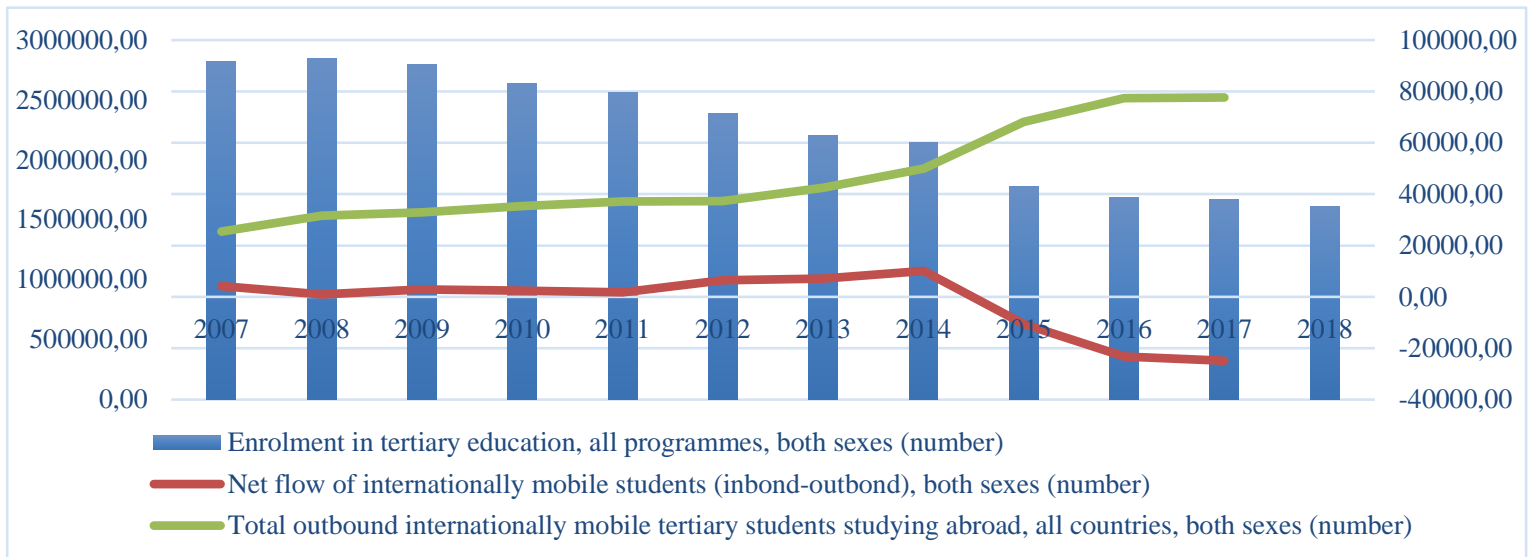

Fig.1: Indicators of enrolment and internationally mobile students, Ukraine (2007-2018)

Source: Composed by the authors on data from the http://data.uis.unesco.org/. Data downloaded in June 2020

The empirical data shows that the net flow of internationally mobile students (outbound - inbound) in Ukraine has a negative growing importance. The most interesting countries for studying abroad are EUcountries, Russia, USA and Canada. For instance, in 2017 the number of Ukrainian students enrolled in fulltime programs in the Ukrainian HEIs (universities, academies and institutes) were more than 900 thousand, and about $8 \%$ of them has studied abroad. Mostly, they prefer to study in Poland, Russia,

Does the decline in demand for higher education in home countries in the global world could be driven by the level of competitive higher education system or the models and forms of its funding and the costs of education? We will try to find the answer to this question in our paper.

Our empirical study based on the evidence of the following middle- and high-income European countries (according to the World Bank classification), which cause the greatest interest for Ukrainian students to study: Ukraine, Hungary, Poland, Bulgaria, Czech Republic and Slovak Republic. Adequacy, relevance and completeness of indicators and statistics for analysis is provided by original sources from World
Germany, Canada, Czech Republic, Italy, USA, Spain, Austria, France, Slovakia. These countries receive more than $90 \%$ of all Ukrainian students studying abroad. In general, the number of outbound internationally mobile Ukrainian tertiary students has more than tripled for the last ten years. Among all European countries, except Germany, the largest increase in outbound mobility recorded by Poland, Czech Republic, Slovakia, Austria, Italy, Spain and Bulgaria (fig.2).

Bank Statistics, The UNESCO Institute for Statistics, World Economic Forum Global Competitiveness Index, official government statistics of Ukraine. The time frames presented for the last 15 years is limited to official statistics from the sources identified above. From our point of view, according to the current issues in reforming higher education in Ukraine, this period is quite representative.

We have carried out current studies on the quality and attractiveness of higher education and rejected all other factors that may affect on the attractiveness of the higher education system in the country, such as, regional, social and economic environment, demographic, etc. We have concentrated 
our research on estimation how the competitiveness of higher education is determined by the quality of the higher education system and its attractiveness.

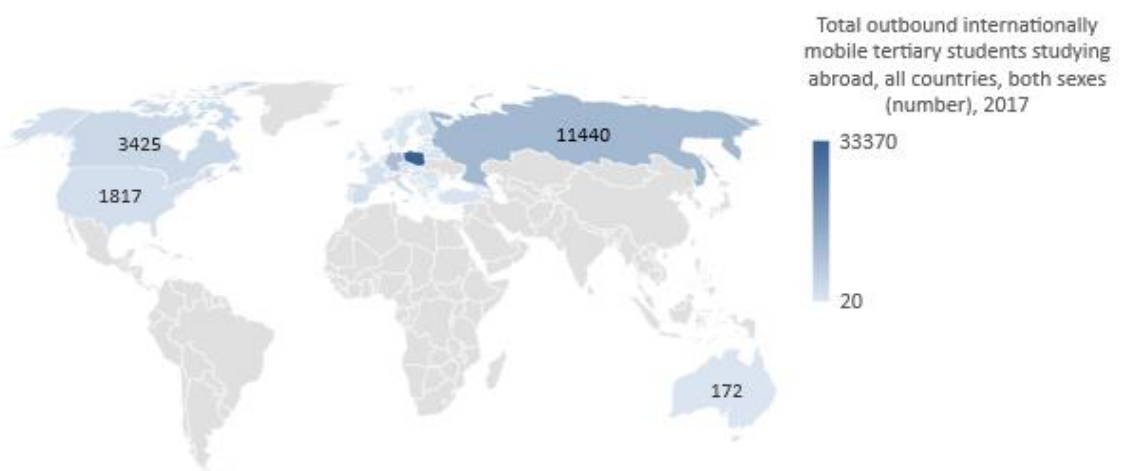

Fig. 2: Total outbound internationally mobile Ukrainian tertiary students studying abroad, all countries, 2017 Source: Composed by the authors on data from the https://cedos.org.ua/.

In addition, having previously assessed empirical data on models and forms of funding of higher education in selected countries, it can be noted that most students study in public institutions funded by the government. At the same time, the level of government spending on higher education in these countries ranges from 1 to $2.2 \%$ of GDP, which is the average rate for the EU countries. Moreover, Ukraine has the highest expenditures on higher education in GDP per capita among the studied countries (fig. 3).
The study states several hypotheses.

Hypothesis 1. Increasing the level of an academic attractiveness and the quality of education have a positive effect on the competitiveness of higher education.

Hypothesis 2. Competitiveness of higher education depend on the prevailing role of government quote on higher education (per student).

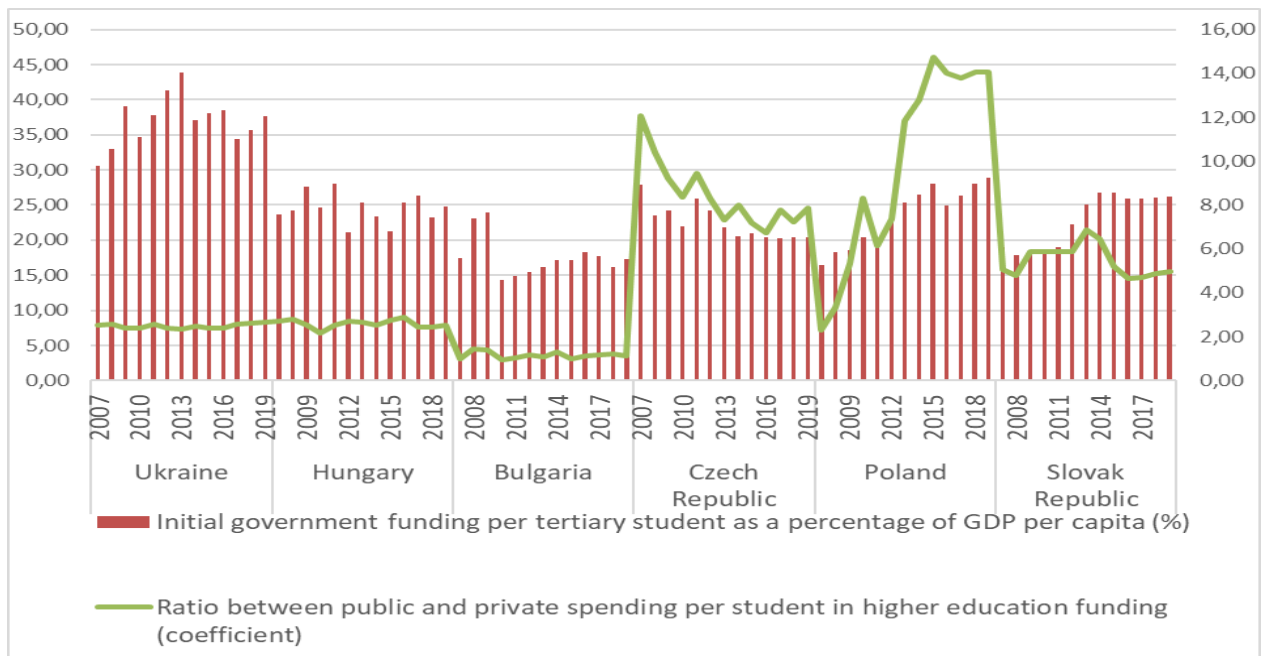

Fig.3: Government spending on tertiary education in European countries, 2007 - 2019

Source: Composed by the authors on data from the http://data.uis.unesco.org/. Data downloaded in June 2020

It can be noted that the classification of variables into endogenous and exogenous is conditional and depends on the substantive concept of the adopted model. In our case, all variables, measured and latent, interact with each other, however, the nature of these interactions is established by the hypotheses stated above. It's needed to be considered the following assumptions testing our hypotheses:
1. The competitiveness of the higher education system is determined by its quality, collaboration with business in development and research, and the level of skillset acquired by the applicant that meet the needs of the labor market.

2. Competitiveness can be positively influenced by the attractiveness of the higher education system in 
the country and the prevailing role of the state (state quota) in financing education.

In addition, in two cases - a case study from Ukraine and case from selected European countries - a regression analysis was performed to identify the relationships between the sought variables. The obtained results indicate that all the variables we have chosen somehow determine each other (i.e., make up a causal pair).

Based on the objective of the study, our assumption will be that the four indicators from the first hypothesis for all the countries studied became independent determinant variables in our study, namely: Quality of the educational system (5Pillar Higher education and training); University-industry collaboration in R\&D; Skillset of university graduates; Capital expenditure as a percentage of total expenditure in public institutions. There are the following indicators of the second hypothesis, which affect competitiveness of higher education system attractiveness of higher education system and forms and model of funding in higher education system. There are the following dependent variables - Ratio between public and private spending per student in higher education funding (coefficient); Inbound mobility rate; ICT access; Gross enrolment ratio, tertiary; Percentage of enrolment in tertiary education in public institutions. At the same time, for the possible construction of relations between the selected indicators, their units of measurement were reduced to comparable values.

Another feature of the models was the limited statistics on certain indicators of selected countries. Therefore, there are insignificant differences in the coefficients of the constructed models and in the unintentional removal of non-influential factors from the models. The analysis was carried out using $\mathrm{R}$ software. Two models were used for the analysis, specifically: for Ukraine and for other investigated countries.

\section{Results and Discussions}

\subsection{Testing hypotheses by modeling structural equations for Ukraine}

Based on empirical data for the last 10-15 years (the study interval was determined by the availability of data in the used statistical databases), we construct a recursive model and a path diagram (path diagram, Blau, Duncan, 1967 [20]), which determines the impact on the competitiveness of the higher education system of its attractiveness and the prevailing role of public finance. The main assumption of the model is that the influence of exogenous and lag variables is conditionally independent and they do not introduce an additional error in estimating the values of endogenous variables.

To build a recursive model, we use the following variables. The independent variables are (which determine the competitiveness of the higher education system specified in the model): V1 - Quality of the educational system (5Pillar Higher education and training); V2 - University-industry collaboration in R\&D; V3 - Skillset of university graduates. The dependent variables are, CMP - competitiveness of higher education system, ATT - attractiveness of higher education system, GOV - forms and financial model of higher education system: V5 - Ratio between public and private spending per student in higher education funding (coefficient); V6 - Inbound mobility rate; V8 - ICT access; V9 - Gross enrolment ratio, tertiary; V10 - Percentage of enrolment in tertiary education in public institutions.

Using the software R, we express it as follows: measurement model $C M P=f(V 1, V 2, V 3)$; $A T T=f(V 9, V 6) ; G O V=f(V 8, V 10, V 5) ;$

(1)

$$
\text { regressions } A T T \sim C M P ; G O V \sim A T T+C M P
$$

$$
\text { residual correlation } V 9 \sim \sim V 10+V 6 ; V 9 \sim \sim 88
$$$$
+V 5 ; V 6 \sim V 8
$$

where the first block $(\mathrm{CMP}=\mathrm{f}(\mathrm{V} 1, \mathrm{~V} 2, \mathrm{~V} 3), \mathrm{ATT}=\mathrm{f}$ $(\mathrm{V} 9, \mathrm{~V} 6), \mathrm{GOV}=\mathrm{f}(\mathrm{V} 8, \mathrm{~V} 10, \mathrm{~V} 5))$ are independent determinant variables, the second block of equations (ATT CMP, GOV ATT + CMP) determines how dependent variables are calculated. Finally, the third block (V9 V10 + V6, V9 V8 + V5, V6 V8) sets the pattern of correlation relations between exogenous variables that are related to each other.

To analyze the model, the obtained results are displayed on the path diagram (Fig. 4).

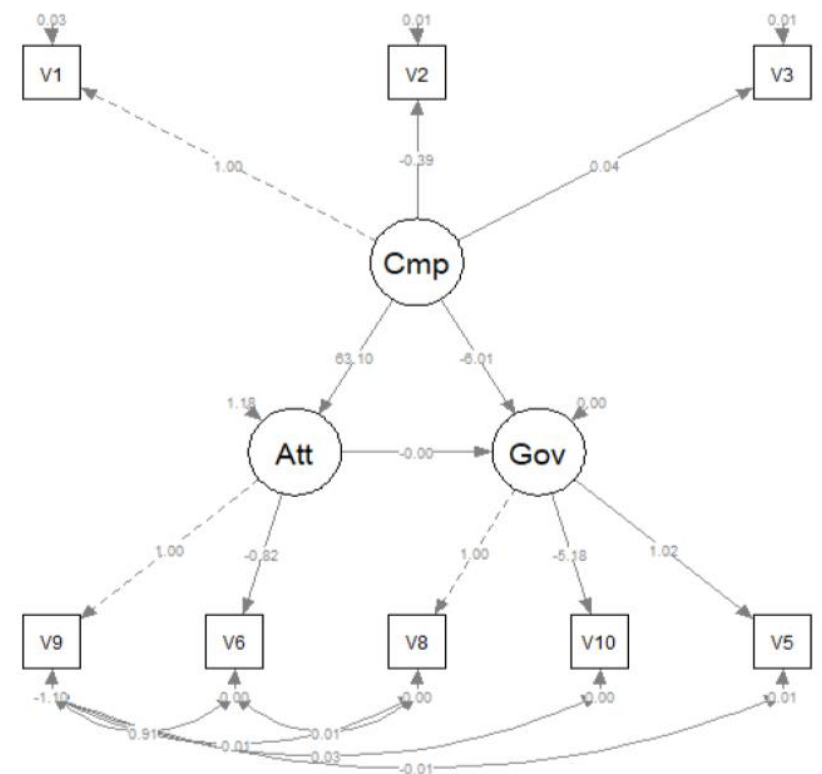

Fig.4: Results of the Testing the Hypothesizes (for Ukraine) 
Source: Own elaborations

In the path diagram (Fig.4), latent variables are indicated ovals, and the observed ones with rectangles, the causal pair is connected one-way arrow coming from independent to dependent variable. Covariance bonds are indicated by two-way arrows. Above the arrows affixed the values of the coefficients of the model. The model was checked for adequacy by testing RMSEA (0.09) with the output of their corresponding p-values, as well as the quality index of the fit of the tested model compared to the "maximum saturated" (CFI - Comparative Fit Index - 0.8). The results showed sufficient adequacy of the studied model and the absence of autocorrelation.

Figure 4 data allows us to draw the following results:

1. The competitiveness (CMP) of the Ukrainian higher education system is determined by the quality of education ( $\mathrm{V} 1$, regression coefficient 1,0$)$ to a greater extent than by accelerating the processes of collaboration between universities and business in R\&D (V2, -0,39) and improving the quality of skillset graduates from universities (V3, -0,04). At the same time, an inverse relationship between competition and

4.1 Testing hypotheses by modeling structural equations for European countries of a comparable region in which Ukrainian students prefer to study (Ukraine, Hungary, Bulgaria, Czech Republic, Slovak Republic, Poland)

Based on the data of the World Bank and the UN over the past 10-15 years in the field of higher education, we construct path diagrams based on the following system of structural equations.

To build a recursive model, use the independent variables (which determine the competitiveness of the higher education system specified in the model) - V1 Quality of the educational system (5Pillar Higher education and training); V2 - University-industry collaboration in R\&D; V3 - Skillset of university graduates; V5 - Capital expenditure as a percentage of total expenditure in public institutions; the dependent variables - CMP - competitiveness of higher education system, ATT - attractiveness of higher education system, GOV - forms and financial model of higher education system: V8 - Ratio between public and private spending per student in higher education funding (coefficient); V11 - Inbound mobility rate; V14 - ICT access; V15 - Gross enrolment ratio, tertiary; V16 - Percentage of enrolment in tertiary education in public institutions.

Similar to the algorithm described in paragraph 4.1, using the software R, we express it as follows:

measurement model $C M P=f(V 1, V 2, V 3$, $V 13) ; A T T=f(V 11, V 14, V 15) ; G O V=f(V 5, V 8, V 16)$ development in the field of research is observed in the study period. The determining factor in increasing competitiveness is the attractiveness of the Ukrainian higher education system.

2. The attractiveness of the higher education system in Ukraine is more expressed in the interest of applicants in their own country (V9, 1,0), while for students from abroad it is not a priority (V6, -0,82). The interest of the latter is caused, among other things, by insufficiently developed access to ICT.

3 . The model and form of financing depends (V5, 1,02) on the number of students studying in state institutions (V10, -5,18) and is determined by the ratio of sources of financing in the studied country.

Thus, hypothesis 1 is confirmed, i.e. competition (CMP) is determined by the quality of higher education and its attractiveness (ATT, 63,1), which in turn expresses the interest of applicants in their own country. Regarding hypothesis 2 , the results of the constructed model do not provide unambiguous confirmation of the significant dependence of the competitiveness of the higher education system on the existing form of its financing (the prevailing role of the state).

regressions $\quad A T T \sim C M P ; G O V \sim A T T+C M P$

$$
\text { residual correlation } \quad \text { V15 V16+V11; V8 }
$$

V14; V5 V14

where the first block $(\mathrm{CMP}=\mathrm{f}(\mathrm{V} 1, \mathrm{~V} 2, \mathrm{~V} 3, \mathrm{~V} 13)$, $\mathrm{ATT}=\mathrm{f}(\mathrm{V} 11, \mathrm{~V} 14, \mathrm{~V} 15), \mathrm{GOV}=\mathrm{f}(\mathrm{V} 5, \mathrm{~V} 8, \mathrm{V16}))$ are independent determinant variables, the second block of equations (ATT $\sim$ CMP, GOV $\sim$ ATT + CMP) defines a method for calculating dependent variables. Finally, the third block (V15 V16 + V11, V8 V14, V5 V14) sets the pattern of correlation relationships between exogenous variables that are linked together.

To analyze the model the obtained results are displayed on the path diagram (Fig. 5). The results (RMSEA 0.06, CFI 0.76) showed sufficient adequacy of the studied model and the absence of autocorrelation. 


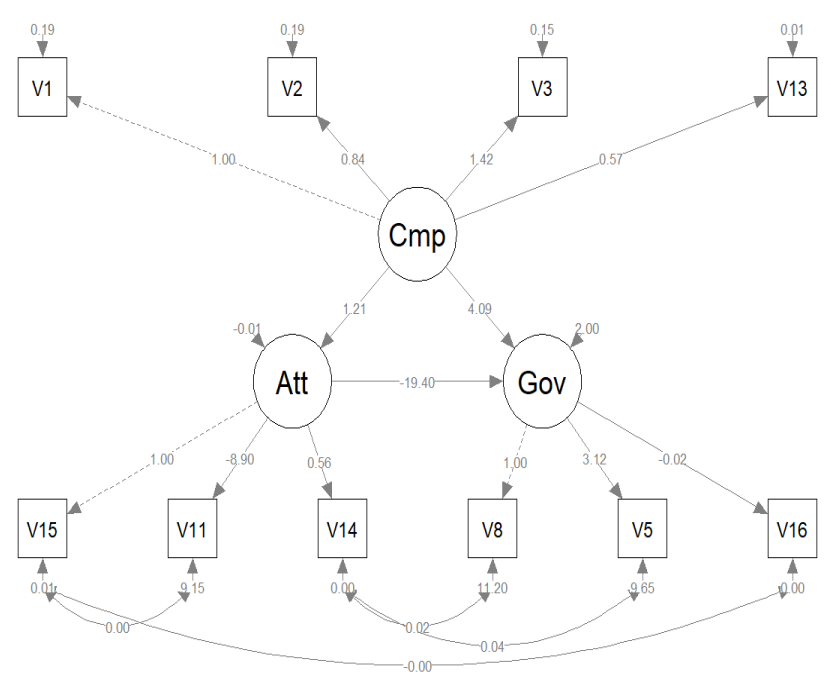

Fig.5: Results of the Testing the Hypothesizes (for Ukraine, Hungary, Bulgaria, Czech Republic, Slovak Republic, Poland)

Source: Own elaborations results:

Figure 5 data enables us to draw the following

1. The competitiveness of higher education systems in the studied countries is determined by the quality of education $(\mathrm{V} 1,1,0)$ to a lesser extent than by improving the quality of skills $(\mathrm{V} 3,1,42)$ acquired by graduates of universities, and to a significant degree by accelerating the processes of collaboration between universities and business in $R \& D(V 2,0,84)$. At the same time, there is a direct relationship between competition and development in the field of research. The determining factor in changing competitiveness is to a greater extent the form and model of financing education. It is interesting that any changes in the form and sources of funding of higher education are determined precisely by the attractiveness of this area. In other words, existing financing models are effective in terms of increasing students' interest in choosing a particular country for study.

2. The attractiveness of the higher education system is less expressed by the interest of applicants in their own country, while for students from abroad it is a priority. The interest of the latter is due to the volume of financing capital expenditures of public educational institutions in these countries (V5, 3,12).

3. The model and form of financing [22] determines the direction of the use of funds in favor of development costs and the ratio of sources of financing $(\mathrm{V} 8,1,0)$ in the studied country, and to a lesser extent, depends on the number of students in public institutions (V16, -0,02).

Therefore, hypotheses 1 are confirmed, i.e. competition (CMP) is determined by the quality of higher education and its attractiveness, which in turn expresses the interest of applicants in their own country. Regarding hypothesis 2 , the results of the constructed model provide confirmation of the dependence of the competitiveness of the higher education system on the existing form of its financing (the direction of using funds in favor of development costs and the ratio of funding sources in the studied country). But they do not answer the question about the prevailing role of state financing of higher education.

\section{Conclusion}

The analysis of the competitiveness, attractiveness and financing of the higher education system makes it possible to determine the cause-effect relationships between the factors affecting the demand for higher education both in the middle of the country and abroad. The trend of recent years shows an increased interest of students in international mobility. Unfortunately, this process can both positively and negatively affect the attractiveness and competitiveness of higher education in the home country. In particular, statistics of migratory students from Ukraine has a negative net flow.

To assess the possibilities of increasing the competitiveness and quality of education in order to attract students' global interest in home country education, we examined two models of the interconnections of factors influencing these processes. Three important conclusions can be drawn: for the Ukrainian model, it is important to build a competitive system of higher education, while in the selected countries where our students gravitate, the emphasis is on the acquired skills and the applied aspect of education; in European countries, financing models are convenient not only for students in these countries, but also attractive for students from abroad, including Ukraine; in the structure of costs for financing higher education institutions, development costs are significant for competitiveness and attractiveness, which is not typical for the Ukrainian system of financing higher education. The number of students is not a priority in the countries where our student migrates to obtain quality skillset.

Thus, the hypotheses put forward were partially confirmed. This research has several limitations. Firstly, the sample is limited by Eastern and Central European countries. Secondly, the time length for our study is limited to the years 2007-2019, because a of availability most of indicators for this period. Thirdly, there are only certain indicator of competitiveness, attractiveness and forms of funding for higher education that were tested. The research will be continued in the future to eliminate mentioned limitations.

Our findings point out the importance of correlation between funding and academic 
attractiveness of higher education are influenced by many determinants in specific ways that makes it not easy. Additionally, the knowledge on competitiveness and attractiveness under conditions of globalization of education is underestimated at the present in terms on forms of funding. And it is needed for the improvement of higher education managing processes. The perspective of further studies is development of funding in higher education institutions on the basis of quality and attractiveness of higher education.

\section{References:}

[1] Ozturk, Il. (2001) The Role of Education In Economic Development: A Theoretical Perspective. Journal of Rural Development and Administration, Volume XXXIII, No. 1, Winter, pp. 39-47.

[2] Woessmann, L. (2014) The Economic Case for Education. EENEE Analytical Report No. 20. URL:

http://www.eenee.de/dms/EENEE/Analytical_Re ports/EENEE_AR20.pdf.

[3] World Economic Forum (2016) Global Competitiveness Report 2015-2016. URL: http://reports.weforum.org/globalcompetitiveness-report-20152016/education/\#view/fn-53.

[4] Barro, R. J. and J.-W. Lee. (2010) A New Dataset of Educational Attainment in the World, 1950 2010. NBER Working Paper No. 15902. Cambridge, MA: National Bureau of Economic Research.

[5] IIASA (2008) Economic Growth in Developing Countries: Education Proves Key, Policy Brief \#3.

URL:

http://www.iiasa.ac.at/web/home/resources/publi cations/IIASAPolicyBriefs/pb03-web.pdf.

[6] Woessmann, L (2015) The economic case for education, Education Economics, Volume 24. URL:

http://www.tandfonline.com/doi/abs/10.1080/096 45292.2015.1059801 ?journalCode $=$ cede20.

[7] UNESCO (2012) UNESCO Global Monitoring Report.

URL: http://unesdoc.unesco.org/images/0021/002180/2 18003e.pdf

[8] Hanushek, E.A., Woessmann, L. in Dominic J. Brewer and Patrick J. McEwan (2010) Economics of Education, Amsterdam: Elsevier, 2010, pp. 6067[reprinted in Eva Baker, Barry McGaw and Penelope Peterson (ed.), International Encyclopedia of Education (Amsterdam: Elsevier, 2010), pp. 245-252]. URL: http://hanushek.stanford.edu/publications/educati on-and-economic-growth
[9] Liping Liao, Minzhe Du, Bing Wang and Yanni Yu. (2019) The Impact of Educational Investment on Sustainable Economic Growth in Guangdong, China: A Cointegration and Causality Analysis. URL:

https://res.mdpi.com/d_attachment/sustainability/ sustainability-11-

00766/article_deploy/sustainability-11-

00766.pdf.

[10] Pranevičienè, B., Pūraitè, A. (2010). The Financing Methods of Higher Education System. Jurisprudence. 2010. No. 4 (122). P. 335-356. URL: $\quad$ https://www.mruni.eu/ upload/iblock/a2d/18_Praneviciene.pdf.

[11] Funding and fiscal incentive mechanisms for investments in science and education: monograph. Ed. by Tetiana Iefymenko; science ed. Alla Sokolovska, Kyiv, SESE "The Academy of Financial Management", 2018, 448 p.

[12] Miller, Tr. (2016) Higher education outcomes based funding models and academic quality. URL:

https://www.luminafoundation.org/files/resource s/ensuring-quality-1.pdf.

[13] Chernova, E., Akhobadze, T., Malova, A., Saltan A. (2017) Higher Education Funding Models and Institutional Effectiveness: Empirical Research of European Experience and Russian Trends. Voprosy obrazovaniya, Educational Studies Moscow, 2017, No 3, P. 37-82. URL: https://www.researchgate.net/publication/320254 120_Higher_Education_Funding_Models_and_I nstitutional_Effectiveness_Empirical_Research_ of_European_Experience_and_Russian_Trends.

[14] An attractiveness index to determine the hierarchical differentiation within higher education. URL: https://ips.gu.se/digitalAssets/824/824795_Attrac tiveness_index.pdf

[15] Hayrapetyan, G., Hayrapetyan, V. (2009). The Determinants of the Attractiveness of National Higher Education System, EERC Working Paper Series 09/08e, EERC Research Network, Russia and CIS. URL: https://ideas.repec.org/p/eer/wpalle/09-08e.html.

[16] Cattaneo, M., Horta, H., Malighetti, P., Meoli, M. and Paleari, S. (2019) Universities' attractiveness to students: The Darwinism effect. Higher Education Quartely. Volume 73, Issue 1, P. 85 99.

URL: https://onlinelibrary.wiley.com/doi/full/10.1111/ hequ.12187.

[17] Brennan, J., Broek, S., Durazzi, N., Kamphuis, B., Ranga, M. and Ryan, S. (2014) Study on innovation in higher education: final report. 
European Commission Directorate for Education and Training Study on Innovation in Higher Education, Publications Office of the European Union, Luxembourg. URL: http://www.lse.ac.uk/business-andconsultancy/consulting/assets/documents/studyon-innovation-in-higher-education.pdf.

[18] Schneller, Ch. and Holmberg, C. (2014) Distance education in European higher education -the students. UNESCO Institute for Lifelong Learning, International Council for Open and Distance Education and StudyPortals B.V. URL: https://static1.squarespace.com/static/5b9966467 5f9eea7a3ecee82 /t/5c7e4af8b208fc99771b9d7e/1551780606067/i deal-report-2-final.pdf.

[19] Trines, S. (2018) Educating the Masses: The Rise of Online Education in Sub-Saharan Africa and South Asia. URL: https://wenr.wes.org/2018/08/educating-themasses-the-rise-of-online-education.

[20] Blau, P. M., \& Duncan, O. D. (1967). The American occupational structure. John Wiley \& Sons Inc. URL: https://books.google.ru/books?id=14dEAAAAIA AJ\&dq=editions:LCCN67019939\&hl=ru

[21] Aleksieieva, N., Kotina, H., Stepura, M. (2015). Peculiarities of Calculating the Cost of Public Goods (from the Necessary to the Desired): Domestic Realities and European Experience / Problems of Economy. Issue 4. P. 7-16. (in Ukrainian). URL: http://nbuv.gov.ua/UJRN/Pekon_2015_4_2

[22] Bilinets, M., Hladchenko, L., Paientko T., Government Financial Support of Higher Education and its Role in Economic Prosperity of a Society. ICTERI Workshops 2019, pp. 473-484. URL: http://ceur-ws.org/Vol2393/paper_419.pdf

[23] Gontareva, I., Borovyk, M., Babenko, V., Perevozova, I., Mokhnenko, A. (2019) Identification of Efficiency Factors for Control over Information and Communication Provision of Sustainable Development in Higher Education Institutions, WSEAS Transactions on Environment and Development, pp. 593-604, Volume $15 . \quad$ URL: https://www.wseas.org/multimedia/journals/envir onment/2019/b245115-062.pdf

[24] Jarkovsky, R., Major, S., Cyrus, P. (2018) The 3DPrint in Technical Education and Creativity Development, WSEAS Transactions on Environment and Development, pp. 668-673, Volume $14 . \quad$ URL: https://www.wseas.org/multimedia/journals/envir onment/2018/b425915-095.pdf

[25] Ribaj, A., Meçe, M., Cinaj, V., Kadrim, I. (2020) Issues Related to Financial Education of Youth in a Developing Country (The Case of Albanian Youth), WSEAS Transactions on Business and Economics, ISSN / E-ISSN: 1109-9526 / 22242899, Volume 17, Art. \#16, pp. 140-152. URL: https://www.wseas.org/multimedia/journals/econ omics/2020/a325107-081.pdf

[26] Paientko, T., Fedosov, V. (2018) Can information technology increase government effectiveness? ICTERI Workshops 2019, pp. 393-405. URL: http://ceur-ws.org/Vol-2393/paper_315.pdf

\section{Contribution of individual authors to the creation of a scientific article (ghostwriting policy)}

Hanna Kotina, Maryna Stepura carried out the Methodology and Testing hypotheses by Modeling structural equations $(4.1,4.2)$.

Denys Hrysohlazov, Marina Bilinets were responsible for the Literature Review.

Viktor Fedosov has executed the Introduction and Conclusions.

Hanna Kotina, Maryna Stepura was responsible for the Statistics.

\section{Creative Commons Attribution License 4.0 (Attribution 4.0 International, CC BY 4.0)}

This article is published under the terms of the Creative Commons Attribution License 4.0 https://creativecommons.org/licenses/by/4.0/deed.en_US 